AGRO EKONOMI, Vol 29, Issue 2, December 2018, Page. 207-217

DOI : http://doi.org/10.22146/ae.34323

ISSN 0215-8787 (print), ISSN 2541-1616 (online)

Available at https://jurnal.ugm.ac.id/jae/

\title{
THE EFFICIENCY OF MELINJO (Gnetum Gnemon L.) CHIP SUPPLY CHAIN IN BANTUL REGENCY, PROVINCE OF YOGYAKARTA
}

\section{Efisiensi Rantai Pasok Emping Melinjo di Kabupaten Bantul Daerah Istimewa Yogyakarta}

\author{
Sunendar ${ }^{1}$, Dwidjono Hadi Darwanto ${ }^{2}$, Irham $^{3}$ \\ ${ }^{1}$ Socio-Economics of Agriculture, Faculty of Agriculture, Universitas Soedirman \\ ${ }^{2,3}$ Faculty of Agriculture, Universitas Gadjah Mada \\ ${ }^{1} \mathrm{Jl}$. Dr. Soeparno No 61, Purwokerto, Jawa Tengah \\ 2,3 Jl. Flora No. 1 Bulaksumur, 55281 Yogyakarta, Telp. (0274) 555675 \\ sunendar26@gmail.ugm.ac.id
}

Submitted: 4 April 2018; Revised: 5 August 2018; Accepted: 26 September 2018

\begin{abstract}
Melinjo chip is one of the typical foods in Yogyakarta made of melinjo nuts. The production center of melinjo chip is located in Banguntapan and Pajangan Sub Districts, Bantul District. The purpose of this study is to determine the efficiency of the supply chain measured with transportation model analysis. The number of respondents in this research was 50 producers of melinjo chip in Bantul District, taken by simple random sampling method. While the snawball sampling method was used to get 5 (five) collector traders, 5 (five) large traders and 26 (twenty six) melinjo chip retailers that taken by following melinjo chip sales distribution from the producer to Market of Piyungan, Demangan, Kotagede, Sentul, Beringharjo, Bantul, Legi, and Magelang. The supply chain actors of melinjo chip are melinjo farmers, melinjo chip producers, collecting traders, large traders, retailers, consumers, packaging producers, production workers, haulers, and firewood providers. The analysis of transportation model with minimum cost illustrates that Wirokerten Village from Banguntapan Sub District allocate the production of melinjo chip to Market of Beringharjo and Piyungan, while Potorono Village allocates the to Market of Demangan. Sendangsari and Triwidadi Village from Pajangan Sub District allocate the production of melinjo chip to Market of Beringharjo, while Guwosari Village allocates to Market of Beringharjo, Bantul, and Legi.
\end{abstract}

Keywords: efficiency, supply chain, and transportation.

Sunendar, Darwanto, D.H., \&Irham (2018) The Efficiency of Melinjo (Gnetumgnemon L.) Chip Supply Chain in Bantul Regency, Province of Yogyakarta. Agro Ekonomi, 29(2) : 207-217

\section{INTISARI}

Emping melinjo merupakan salah satu makanan khas Daerah Istimewa Yogyakarta berbahan baku biji melinjo. Sentra produksi emping melinjo berada di Kecamatan Banguntapan dan Kecamatan Pajangan, Kabupaten Bantul. Tujuan penelitian ini adalah menentukan efisiensi rantai pasok dilihat dengan model transportasi. Pengambilan responden dalam penelitian ini dilakukan secara simple random sampling sebanyak 50 produsen emping melinjo di Kabupaten 
Bantul. Metode snowball sampling digunakan untuk mendapatkan lima pedagang pengepul, lima pedagang besar, dan 26 pedagang pengecer emping melinjo dengan cara mengikuti alur penjualan emping melinjo dari produsen ke Pasar Piyungan, Demangan, Kotagede, Sentul, Beringharjo, Bantul, Legi, dan Magelang. Pelaku rantai pasok emping melinjo meliputi petani, pedagang melinjo, produsen emping melinjo, pedagang pengumpul, pedagang besar, pedagang pengecer, konsumen, produsen kemasan, buruh produksi, buruh gendong, dan penyedia kayu bakar. Berdasarkan analisis model transportasi dengan biaya minimum, maka hasil yang didapat adalah Kecamatan Banguntapan dengan sumber Desa Wirokerten mengalokasikan hasil produksi emping melinjonya ke Pasar Beringharjo dan Pasar Piyungan sementara Desa Potorono mengalokasikan ke Pasar Demangan. Kecamatan Pajangan dengan sumber Desa Sendangsari dan Desa Triwidadi mengalokasikan hasil produksi emping melinjonya ke Pasar Beringharjo, sementara Desa Guwosari ke Pasar Beringharjo, Bantul, dan Legi.

Kata kunci: efisiensi, rantai pasok, dan transportasi.

\section{INTRODUCTION}

Indonesia as a developing country where most of the economy growth is supported by Small and Medium Enterprises (SME). Based on data from the Central Bureau of Statistics, states that $90 \%$ - 95\% of companies in Indonesia are classified as SMEs. This shows that Indonesia's economic growth is driven and dominated by SME activities (Aisyah et al., 2013).

One of the horticultural crops that has great a potential to develop is Melinjo (Gnetum genemon, L.). Melinjo plants in some areas as vegetable crop. Melinjo is also a basic ingredient to make melinjo chip. Melinjo chip is one of snacks, besides having high nutrition, it also has a distinctive taste and liked by lot of society. Melinjo chip is a special food from Indonesian (Aliudin \& Anggraeni, 2012).

executing product's flow from producent to costumer is one of many factors that cannot be ignored. It is necessary to choose the right distribution channel to be used in the distribution of goods. Moreover, it will helps the distribution especially in term of prices adjustment in different markets (Cristoporus \& Sulaeman, 2009).

Harjanto (2008) explains that the supply chain is a set of interrelated activities and decisions designed to integrate suppliers, manufacturers, warehouses, transportation services, retailers and consumers efficiently. Thus, goods and services can be distributed with the best quality, quantity, time and location so that it can minimize costs in fulfilling the need of the consumers.

In today's competition, business actors have to consider that the common competition is a competition between supply chain networks. Business actors in a supply chain must be able to deliver products that suit the consumers' desires in terms of quality, quantity, price, time and place (Furqon, 2014).

Network design is an important activity that must be done on supply chain management. Making decisions in 
a network design has a very significant impact or influence. A performance in network design decision making will determine the composition of supply chain management. Hence, integerated supply chain management could increase the overall value generated by these networks (Budiman et al., 2015).

A competitive advantage can depend on long-term strategic relationships that are close to the number of suppliers. Employers should seek the integration of then chosen strategy with in the supply chain. A successful result does not denyv the perseverance of dedication, innovative, and the desire to move forward. Therefore, teamwork, integrity, mutual respect are prioritized in the work environment (Wuwung, 2013).

Kertiasih (2009) in her research about the use of transportation methods for the distribution of goods revealed that transportation methods are used to manage the distribution of sources that provide the same product to places that require optimum. The allocation of these products should be arranged in such a way, as there are differeces in cost from one source to another.

Kertiasih (2009) on transportation problems states that usually the number of goods supplied from each request location varies. The different shipping routes will result in different shipping costs. Furthemore, the solution of this case is by determining how many units of goods are streamed from each source to each destination so that the demand for each goal is met and the total shipping cost is minimum.

Mau (2018) in his research about patterns and determinant factors of arabica coffee's marketing margin in Ngada Regency shows that marketing margin is significantly influenced by marketing volume and marketing cost. Based on the result, marketing volume and marketing cost are the facrors which affected the arabica coffee's marketing as well. So the researcher in interested to do a research about melinjo chip marketing in Bantul District. The problem in this article is related to melinjo chip marketing in Bantul District which is not only marketed in Yogyakarta area but also outside the area such as Magelang market. But, marketing of melinjo chip out of area need higher cost in delivery of goods compared to market in Yogyakarta area. Based on the description above, the problem to be discussed in this research is whether the supply chain of melinjo chip in Bantul District has been efficient. The purpose of this research is to determine the efficiency of supply chain of melinjo chip.

\section{METHODS}

\section{Location and Data}

This research was conducted in Bantul District as it is the center of melinjo chip production in DIY. The selection of 
this location was done purposively by considering that Bantul District is the industrial center of melinjo chip. The research sites located in two sub-districts, namely Banguntapan Sub District and Pajangan Sub District. The data collected consisted of primary data and secondary data. The number of respondents taken by the researchers was 50 who were the producers of melinjo chip located in Banguntapan Sub District and Pajangan Sub District using simple random sampling method. The respondents were collected by using a simple random sampling method because all the producers of melinjo chip in Bantul District are homogenous.

The sample of merchants was taken by applying a snowball technique (snowball sampling) by following the producers to sell melinjo chip. The researcher observed the process of melinjo chip selling from the producers to the consumers (Nurdiani, 2014).

This study uses a transportation model using scientific management application to determine the optimal melinjo chip distribution in minimum cost. In this research, there were five middlemen, five large traders and 26 retailers. Traders of melinjo chip retailers represent eight market destination of supply chain melinjo chip in Bantul District: Piyungan, Demangan, Kotagede, Sentul, Beringharjo, Bantul, Legi, and Magelang market.
Data analysis

Decision variable :

$\mathrm{Xij}=$ Total of melinjo chip from source $\mathrm{i}$ to destination $\mathrm{j}$

$\mathrm{Cij}=$ Operational cost of melinjo chip distribution from source $i$ to $j$ where $\mathrm{i}=1$ (Wiroketen) and 2 (Potorono), $\mathrm{j}=1$ (Beringharjo), 2 (Demangan), 3 (Kotagede), 4 (Sentul), and 5 (Piyungan) for Banguntapan Sub District

Function Purpose:

Minimizing : $Z=C_{1,1} X_{1,1}+C_{1,2} X_{1,2}+C_{1,3}$ $\mathrm{X}_{1,3}+\mathrm{C}_{1,4} \mathrm{X}_{1,4}+\mathrm{C}_{2,1} \mathrm{X}_{2,1}+\mathrm{C}_{2,5} \mathrm{X}_{2,5}$

Constrains: $\mathrm{X}_{1,1}+\mathrm{X}_{1,2}+\mathrm{X}_{1,3}+\mathrm{X}_{1,4}+\mathrm{X}_{1,5}=$ $\mathrm{a}_{1}$ (supply market)

$\mathrm{X}_{2,1}+\mathrm{X}_{2,2}+\mathrm{X}_{2,3}+\mathrm{X}_{2,4}+\mathrm{X}_{2,5}=\mathrm{a}_{2}$ (supply market )

$\mathrm{Xij}=$ Total of melinjo chip from source $\mathrm{i}$ to destination $\mathrm{j}$

$\mathrm{Cij}=$ Operational cost of melinjo chip distribution from source $i$ to $j$ where $\mathrm{i}=1$ (Sendangsari), 2 (Guwosari), and 3 (Triwidadi), $\mathrm{j}=1$ (Magelang), 2 (Beringharjo), 3 (Bantul), and 4 (Sentul) for Pajangan Sub District.

Function Purpose:

Minimizing: $\mathrm{Z}=\mathrm{C}_{1,1} \mathrm{X}_{1,1}+\mathrm{C}_{1,2} \mathrm{X}_{1,2}+\mathrm{C}_{1,3}$ $\mathrm{X}_{1,3}+\mathrm{C}_{1,4} \mathrm{X}_{1,4}+\mathrm{C}_{2,1} \mathrm{X}_{2,1}+\mathrm{C}_{2,2} \mathrm{X}_{2,2}+\mathrm{C}_{3,1} \mathrm{X}_{3,1}$ Constrains : $\mathrm{X}_{1,1}+\mathrm{X}_{1,2}+\mathrm{X}_{1,3}+\mathrm{X}_{1,4}=\mathrm{a}_{1}$ (supply market)

$\mathrm{X}_{2,1}+\mathrm{X}_{2,2}+\mathrm{X}_{2,3}+\mathrm{X}_{2,4}=\mathrm{a}_{2}$ (supply market) $\mathrm{X}_{3,1}+\mathrm{X}_{3,2}+\mathrm{X}_{3,3}+\mathrm{X}_{3,4}=\mathrm{a}_{3}$ (supply market) 


\section{RESULTS AND DISCUSSION}

\section{Supply Chain Network}

The agents of melinjo chip's supply chain in Bantul District are all the people who are involved in melinjo chip distribution process from the producer to the consumer including farmers, Melinjo traders, producers of melinjo chip, collectors traders, large traders, retailers, consumers, packaging equipment providers, slot workers, production workers, and firewood providers.

The role of melinjo farmers and traders is to provide the raw materials of melinjo chip for the producers. The producers of melinjo chip will offer their products to the middlemen, large traders, and retailers. Merchant traders will sell melinjo chip directly to the retailers and some sell-through merchants. Generally, producers sell their products to retailers who will directly sell it to the consumers.

\section{Model analysis}

1. Decision Variables Identification The supply chain of melinjo chip in Bantul District is started from the producers that acquired melinjo seeds as raw material which obtained from traders and farmers melinjo, then processed the melinjo seeds into melinjo chip. The producers sold the melinjo chip through merchant traders, wholesalers, or directly to retailers. Next, retailers sell it to consumers. Retailers in this study were located in Piyungan, Demangan, Kotagede, Sentul, Beringharjo, Bantul, Legi, and Magelang market. This study aims to optimize the costs incurred by

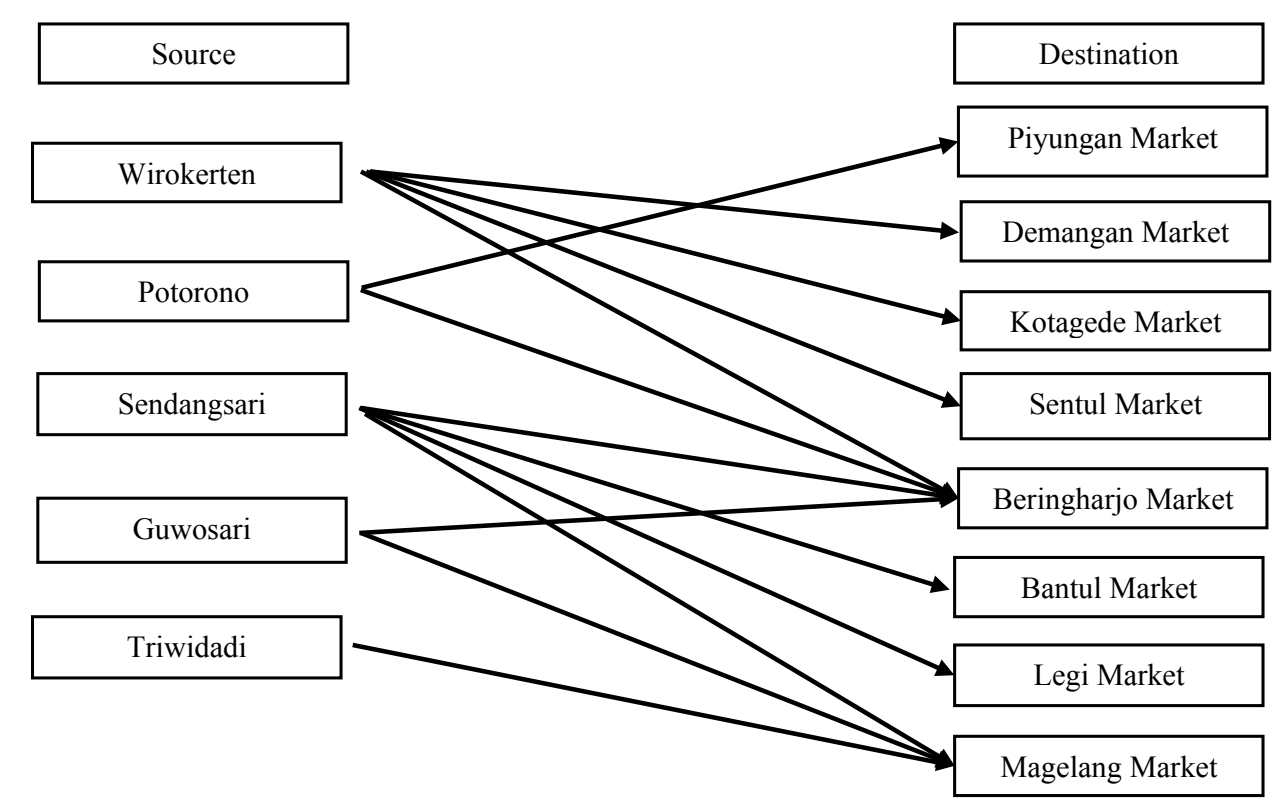

Figure 1. Sources and destinations for the transportation model of melinjo chip in Bantul District. 
producers of melinjo chip in Banguntapan

Sub District consisting of Wirokerten Village, Potorono Village, and Pajangan Sub District which consist of Sendangsari Village, Guwosari Village, and Triwidadi Village.

\section{Constrains Identification}

The constraints in the model are the number of melinjo chip stock from the producers in Bantul District and the needs of melinjo chip of each destination market. The number of needs of each destination market is the result of multiplication between the number of retailers in the destination market and the average of melinjo chip sales for one day then multiplied by seven to know the needs of the destination market within a week. It is the number of needs in a week.

The constraints are:

Constraint needs in each market $=$ the number of melinjo chips sold out by traders in a week

\section{Constraint Equation}

The constraints were divided into two catagories namely the supply and constraints the needs of melinjo chip constrains. Supply constraints is a constraint of the melinjo chip sold by producers within one week $3,827.5 \mathrm{~kg}$, while the needs constraint is the average sales of melinjo chip within a week at the merchant retailers in each market. The needs of melinjo chip retailers in each market can be seen in Table 1 . Melinjo chip demand may increase during Eid al Fitri celebrations, Eid al Adha, and New Year's holiday period. However, the demand of melinjo chip will decrease after Eid al Adha celebrations.

1) Constraints 1 (Needs of Piyungan Market $)=280 \mathrm{~kg}$

2) Constraints 2 (Needs of Demangan Market $)=245 \mathrm{~kg}$

3) Constraints 3 (Needs of Kotagede Market $)=630 \mathrm{~kg}$

4) Constraints 4 (Needs of Sentul Market) $=280 \mathrm{~kg}$

Table 1. The needs of melinjo chips in each market

\begin{tabular}{lcccc}
\hline \multicolumn{1}{c}{ Markets } & Total of Retailers & $\begin{array}{c}\text { Total of sales }(\mathrm{Kg} / \\
\text { Day) }\end{array}$ & $\begin{array}{c}\text { Sales of Markets } \\
(\mathrm{Kg} / \text { Day })\end{array}$ & $\begin{array}{c}\text { Sales of Markets } \\
(\mathrm{Kg} / \text { Week })\end{array}$ \\
\hline Piyungan & 20 & 2 & 40 & 280 \\
Demangan & 35 & 1 & 35 & 245 \\
Kotagede & 15 & 6 & 90 & 630 \\
Sentul & 20 & 2 & 40 & 280 \\
Beringharjo & 35 & 20 & 700 & 4,900 \\
Bantul & 20 & 2 & 40 & 280 \\
Legi & 12 & 2 & 24 & 168 \\
Magelang & 20 & 15 & 300 & 2,100 \\
\hline
\end{tabular}

Source: Primary Data Analysis, 2017 
Table 2. Marketing cost of melinjo chip in each purpose

\begin{tabular}{clrcc}
\hline Source & \multicolumn{1}{c}{ Destination } & Production $(\mathrm{kg})$ & Total Cost(Rp.) & Cost per kg (Rp.) \\
\hline Wirokerten & Beringharjo Market & 740.5 & 155,800 & 210 \\
& Demangan Market & 30 & 17,800 & 593 \\
& Kotagede Market & 60 & 13,600 & 227 \\
& Sentul Market & 22.5 & 16,700 & 742 \\
& Total & 853 & & 58 \\
Potorono & 43 & 2,500 & 493 \\
& Beringharjo Market & 30 & 14,800 & \\
& Piyungan Market & 73 & & \\
& Total & &
\end{tabular}

Source: Primary Data Analysis, 2017

Table 3. The transportation model before minimization in Banguntapan Sub District

\begin{tabular}{|c|c|c|c|c|c|c|}
\hline From & $\begin{array}{l}\text { Beringharjo } \\
\text { Market }\end{array}$ & $\begin{array}{c}\text { Demangan } \\
\text { Market }\end{array}$ & $\begin{array}{c}\text { Kotagede } \\
\text { Market }\end{array}$ & $\begin{array}{l}\text { Sentul } \\
\text { Market }\end{array}$ & $\begin{array}{c}\text { Piyungan } \\
\text { Market }\end{array}$ & $\begin{array}{l}\text { Supply } \\
\text { Market }\end{array}$ \\
\hline Wirolerten & 210 & 593 & 227 & 742 & & $052+4$ \\
\hline Wirokerten & 740.5 & 30 & 60 & 22,5 & & 853 \\
\hline Potorono & 58 & & & & 493 & 73 \\
\hline Demand & 43 & & 630 & 280 & 280 & 026 \\
\hline
\end{tabular}

Source: Primary Data Analysis, 2017

5) Constraints 5 (Needs of Bringharjo

Market $)=4,900 \mathrm{~kg}$

6) Constraints 6 (Needs of Bantul Market)

$=280 \mathrm{~kg}$

7) Constraints 7 (Needs of Legi Market)

$=168 \mathrm{~kg}$

8) Constraints 8 (Needs of Magelang Market $)=2,100 \mathrm{~kg}$

The Analysis of transportation model in Banguntapan Sub District

a. Function purpose:

Distribution of melinjo chip from producer to consumer need of packing cost, transportation, loading and unloading, parking, and retribution. Production of melinjo chip and demand of each market are the results of calculation within a week.
Table 2, is calculation of marketing cost of melinjo chip. Marketing cost is the total cost of production.

Minimizing : $Z=210 X_{1,1}+593 X_{1,2}+$ $227 \mathrm{X}_{1,3}+742 \mathrm{X}_{1,4}+58 \mathrm{X}_{2,1}+493 \mathrm{X}_{2,5}$

Constrains: $\mathrm{X}_{1,1}+\mathrm{X}_{1,2}+\mathrm{X}_{1,3}+\mathrm{X}_{1,4}+\mathrm{X}_{1,5}$ $=853$

$\mathrm{X}_{2,1}+\mathrm{X}_{2,2}+\mathrm{X}_{2,3}+\mathrm{X}_{2,4}+\mathrm{X}_{2,5}=73$

Based on Table 3, the first source, Wirokerten Village, allocates the chips to Beringharjo, Demangan, Kotagede, and Sentul Market of $740.5 \mathrm{~kg}$ costing Rp. 210, $30 \mathrm{~kg}$ costing Rp. 593, $60 \mathrm{~kg}$ costing Rp. 227, and $22.5 \mathrm{~kg}$ costing Rp. 742 respectively.

Potorono Village the secound source allocates the products to two the two destinations namely Beringharjo Market as much as $43 \mathrm{~kg}$ at a cost of Rp. 58, and 
Piyungan Market as much as $30 \mathrm{~kg}$ at a cost of Rp. 493. From both sources, the lowest cost is in Beringharjo Market. Based on the two sources, the sales of melinjo chip are mostly marketed to Beringharjo Market, because the highest number of sales is at Beringharjo and the location is very strategic which close to Malionoro. The Marketing cost of melinjo chip is depend on the amount, the more the less the cost.

Based on Table 3, the total of transportation costs incurred by marketing actors melinjo chip in Pajangan Sub District prior to minimization can be calculated by using using the formula below:

$$
\begin{aligned}
Z= & \sum \text { (operational cost of distribution of } \\
& \text { melinjo chip per kg per supply area } \mathrm{x} \\
& \text { supply quantity) } \\
\mathrm{Z}= & \sum\left(\mathrm{C}_{1,1} \mathrm{X}_{1,1}+\mathrm{C}_{1,2} \mathrm{X}_{1,2}+\mathrm{C}_{1,3} \mathrm{X}_{1,3}+\mathrm{C}_{1,4}\right. \\
& \left.\mathrm{X}_{1,4}+\mathrm{C}_{2,1} \mathrm{X}_{2,1}+\mathrm{C}_{2,5} \mathrm{X}_{2,5}\right) \\
= & \sum\left(210 \mathrm{X}_{1,1}+593 \mathrm{X}_{1,2}+227 \mathrm{X}_{1,3}+\right. \\
& \left.742 \mathrm{X}_{1,4}+58 \mathrm{X}_{2,1}+493 \mathrm{X}_{2,5}\right) \\
= & \sum((210 \times 740,5)+(593 \times 30)+(227 \\
& \mathrm{x} 60)+(742 \times 22,5)+(58 \times 43)+(493 \\
& \mathrm{x} 30)) \\
= & \mathrm{Rp} .220,894
\end{aligned}
$$

Table 4 describes the allocation of melinjo chip from the sources to the destinations in Banguntapan Sub District. There are two sources and five destinations in allocating melinjo chip. The allocation of melinjo chip distribution with the objective of minimizing costs can be seen by using transportation analysis. The operational cost of melinjo chip distribution before being minimized was Rp. 220,894, then the analysis results in table 4 show that the cost of melinjo chip distribution can be reduced to Rp. 120,330, so the operational cost can be minimized to Rp. 100,564.

The lowest marketing costs can be obtained if the producers of melinjo chip in Banguntapan Sub District with the first source of Wirokerten Village allocate the melinjo chip to the first destination which is Beringharjo market with the number of $573 \mathrm{~kg}$ and the fifth destination which is Piyungan Market with the number $280 \mathrm{~kg}$ and the second source which is Potorono Village allocate melinjo chip to the second destination which is Demangan Market with the number of $73 \mathrm{~kg}$.

Table 4. The operational cost of distributing melinjo chip after analysis

\begin{tabular}{cccccc}
\hline \multirow{2}{*}{ Source } & \multicolumn{5}{c}{ Destination } \\
\cline { 2 - 6 } & $\begin{array}{c}\text { Beringharjo } \\
\text { Market }\end{array}$ & $\begin{array}{c}\text { Demangan } \\
\text { Market }\end{array}$ & $\begin{array}{c}\text { Kotagede } \\
\text { Market }\end{array}$ & $\begin{array}{c}\text { Sentul } \\
\text { Market }\end{array}$ & $\begin{array}{c}\text { Piyungan } \\
\text { Market }\end{array}$ \\
\hline Wirokerten & 573 & 0 & 0 & 0 & 280 \\
Potorono & 0 & 73 & 0 & 0 & 0 \\
Total Transportation Cost & & & 120,330 & & 0 \\
\hline
\end{tabular}

Source: Primary Data Analysis, 2017 
The Analysis of transportation model in Pajangan Sub District

Minimizing : $Z=213 X_{1,1}+109 X_{1,2}+$ $493 \mathrm{X}_{1,3}+236 \mathrm{X}_{1,4}+738 \mathrm{X}_{2,1}+228 \mathrm{X}_{2,2}+$ $345 \mathrm{X}_{3,1}$

Constrains :

$\mathrm{X}_{1,1}+\mathrm{X}_{1,2}+\mathrm{X}_{1,3}+\mathrm{X}_{1,4}=1,386$

$\mathrm{X}_{2,1}+\mathrm{X}_{2,2}+\mathrm{X}_{2,3}+\mathrm{X}_{2,4}=1,165$

$X_{3,1}+X_{3,2}+X_{3,3}+X_{3,4}=350$

Sendangsari Village as the first source allocated to the four destinations, which are Magelang Market, Beringharjo, Bantul, and Sentul. Beringharjo market is the destination with the larg-est allocation of melinjo chip of $789 \mathrm{~kg}$ with the lowest cost of Rp. 109. Guwosari Village as the second source allocated to the two destinations, which are Magelang Market and Beringharjo Market. Same with source one, Beringharjo Market destination is the largest allocation amount of $1000 \mathrm{~kg}$ at a cost of Rp. 228. Triwidadi Village as the third source allocated only to one destination, which is Pasar Magelang as much as $350 \mathrm{~kg}$ with the cost of Rp. 345 . From those three sources, the lowest cost is in Beringharjo market just like in the Banguntapan Sub District transportation model. Based on those three sources, almost all of the melinjo chip are marketed to Beringharjo Market. The location of

Table 5. Marketing cost of melinjo chip in each purpose

\begin{tabular}{llccc}
\hline Source & Destination & Production $(\mathrm{kg})$ & Total Cost (Rp.) & Cost per kg (Rp.) \\
\hline Sendangsari & Beringharjo Market & 789 & 86,200 & 109 \\
& Magelang Market & 492 & 104,840 & 213 \\
& Bantul Market & 30 & 14,800 & 493 \\
& Legi Market & 75 & 17,700 & 236 \\
& Total & 1,386 & & \\
Guwosari & Beringharjo Market & 1,000 & 228,000 & 228 \\
& Magelang Market & 165 & 121,720 & 738 \\
& Total & 1,165 & & \\
Triwidadi & Magelang Market & 350 & 120,900 & 345 \\
\hline
\end{tabular}

Source: Primary Data Analysis, 2017

Table 6. The transportation model before being minimized in Pajangan Sub District

\begin{tabular}{|c|c|c|c|c|c|}
\hline To & Magelang Market & Beringharjo Market & Bantul Market & Legi Market & Supply \\
\hline \multirow{2}{*}{ Sendangsari } & 213 & 109 & 493 & 236 & \\
\hline & 492 & 789 & 30 & 75 & 1,386 \\
\hline Guwosari & 738 & 1000 & & & 1,165 \\
\hline Triwidadi & 345 & & & & 350 \\
\hline Demand & 2,100 & 4,900 & 280 & 168 & 2,901 \\
\hline
\end{tabular}

Source: Primary Data Analysis, 2017 
Table 7. The operational cost of melinjo chip distribution after analysis

\begin{tabular}{ccccc}
\hline \multirow{2}{*}{ Source } & \multicolumn{4}{c}{ Destination } \\
\cline { 2 - 5 } & Magelang Market & Beringharjo Market & Bantul Market & Legi Market \\
\hline Sendangsari & 0 & 1,386 & 0 & 0 \\
Guwosari & 0 & 717 & 280 & 168 \\
Triwidadi & 0 & 350 & 0 & 0 \\
Total Transportation Cost & & 314,550 & & \\
\hline
\end{tabular}

Source: Primary Data Analysis, 2017

Beringharjo is near from the producers, that is why many producers sell the melinjo chip at Beringharjo Market. The Marketing cost of melinjo chip is depend on the amount, the more the less the cost.

From Table 6 total transportation costs incurred by marketing agent of melinjo chip in Pajangan Sub District before being minimized can be calculated using the formula:

$\mathrm{Z}=\sum$ (operational cost of distribution of melinjo chip per kg per supply area $\mathrm{x}$ supply quantity)

$$
\begin{aligned}
Z= & \sum\left(C_{1,1} X_{1,1}+C_{1,2} X_{1,2}+C_{1,3} X_{1,3}+C_{1,4}\right. \\
& \left.X_{1,4}+C_{2,1} X_{2,1}+C_{2,2} X_{2,2}+C_{3,1} X_{3,1}\right) \\
= & \sum\left(213 X_{1,1}+109 X_{1,2}+493 X_{1,3}+\right. \\
& \left.236 X_{1,4}+738 X_{2,1}+228 X_{2,2}+345 X_{3,1}\right) \\
= & \sum((213 \times 492)+(109 \times 789)+(493 \\
& x 30)+(236 \times 75)+(738 \times 165)+ \\
& (228 \times 1,000)+(345 \times 350)) \\
= & \text { Rp. 693,807 }
\end{aligned}
$$

Table 7 is the allocation of the distribution of melinjo chip from the sources to the destinations in Pajangan Sub District. There are three sources and four destinations in allocating melinjo chip. The allocation of melinjo chip distribution with the objective of minimizing costs can be seen by using transportation analysis. Operational cost of melinjo chip distribution before being minimized was Rp. 693,807. Then, the analysis results show that the cost can be reduced to Rp. 314,550 . Furthermore, the operational cost is decreased of Rp. 379,257.

The lowest marketing costs can be obtained if the producers of melinjo chip in Banguntapan Sub District with the first source which is Village Sendangsari allocates melinjo chip to the second destination which is Beringharjo Market with the number of $1,386 \mathrm{~kg}$. The second source is Guwosari Village allocating melinjo chip to the second destination in Beringharjo market of $717 \mathrm{~kg}$ , followed by the third destination is Bantul market of $280 \mathrm{~kg}$, and finished is Legi market of $168 \mathrm{~kg}$. The third source is Triwidadi Village allocating melinjo chip to the second destination of Beringharjo market of $350 \mathrm{~kg}$.

\section{CONCLUSION AND SUGGESTION}

Based on the analysis of transportation model with minimum cost, the results are Banguntapan Sub District with Wirokerten 
Village source allocates melinjo chip to Beringharjo and Piyungan Market while Potorono Village allocated to Demangan Market. Sub District of Pajangan with the sources of Sendangsari Village and Triwidadi Village allocate melinjo chip to Beringharjo Market, while Guwosari Village allocates it to Beringharjo Market, Bantul Market, and Legi Market.

The result of transhipment model illustrate that the cost of melinjo chips marketing can be minimized, so the producers should allocate on to markets that mention in transhipment model.

\section{REFERENCES}

Aisyah, M. N., Nugroho, M. A., \& Sagoro, E. M. (2013). Pengaruh Technology Readiness Terhadap Penerimaan Teknologi Komputer Pada Umkm Di Yogyakarta. Jurnal Economia, 10, 105-119.

Aliudin, \& Anggraeni, D. (2012). Nilai Tambah Emping Melinjo Melalui Teknologi Produksi Konvensional di Desa Menes Kecamatan Menes Kabupaten Pandeglang. AGRIKA, 6(1), 23-33.

Budiman, C., Massie, J., \& Wullur, M. (2015). Identifikasi Desain Jaringan Manajemen Rantai Pasok Kopra di Kota Manado. Jurnal Riset Ekonomi, Manajemen, Bisnis Dan Akuntansi, $3(2), 65-76$.
Cristoporus, \& Sulaeman. (2009). Analisis Produksi dan Pemasaran Jagung di Desa Labuan Toposo Kecamatan Tawaeli Kabupaten Donggala. Agroland, 16(2), 141-147.

Furqon, C. (2014). Analisis Manajemen dan Kinerja Rantai Pasokan Agribisnis Buah Stroberi di Kabupaten Bandung. Image, III, 109-126.

Harjanto, E. (2008). Manajemen Produksi dan Operasi (edisi kedu). Jakarta: PT Gramedia Widiasarana Indonesia.

Kertiasih, N. K. (2009). Penggunaan Metode Transportasi Dalam Program Linier Untuk Pendistribusian Barang. JPTK, 6, 27-35.

Mau, M. C. (2018). Patterns and Determinant Factors Of Arabica Coffee's Marketing Margin In Ngada Regency. Agro Ekonomi, 29(1), 102-117.

Nurdiani, N. (2014). Teknik Sampling Snowball Dalam Penelitian Lapangan. ComTech, 5(2), 11101118.

Wuwung, S. C. (2013). Manajemen Rantai Pasokan Produk Cengkeh Pada Desa Minahasa Selatan. Jurnal EMBA, 1(3), 230-238. https://doi.org/23031174 